\title{
Timbuktu Civilization and its Significance in Islamic History
}

\author{
Abdi O. Shuriye \\ Dauda Sh. Ibrahim \\ Faculty of Engineering \\ International Islamic University Malaysia \\ E mail: shuriye@hotmail.com
}

\section{Doi:10.5901/mjss.2013.v4n11p696}

\section{Abstract}

Timbuktu civilization began as a seasonal settlement for trade caravans in the early 11th century. It later flourished in trade and as one of the early African centres of Islamic culture. This paper reviews the trend of Timbuktu civilization from prehistoric period up to the current state of its political impact of the region. The paper further focuses on the role Timbuktu played in African history by serving as academic and commercial centre. The significant of this paper is to reveal the fact that Africa has a long Islamic civilization. The paper provides evidences from reliable sources of the symbolic representation of the impact and influence of the early schools and universities between 11th and 15th century that existed in West Africa. The manuscript of Timbuktu serves as a living testimony of the highly advanced and refined civilization in Africa during the middle ages. The history of monuments, artefacts as well as architectural land marks that signifies the historical origin of this ancient city is presented. The early heroes that stood firm towards the development and civilisation of Timbuktu are outlined. Analysis of the development as well as the factors that led to the civilization is presented in this paper.

Keywords: Timbuktu, civilization, Islamic History, Africa.

\section{INTRODUCTION}

Timbuktu is a city situated in the West African nation of Mali. The fable city lies in the Sahel- the southern edge of the Sahara, eight miles north of Niger River in Mali. Founded by the Tuareg nomads in the $12^{\text {th }}$ Century, Timbuktu region is one of the eight administrative regions of Mali which had about 54,453 people in 2009 census (Resultats provisiores RGPH, 2009).

Geographical Location of Timbuktu

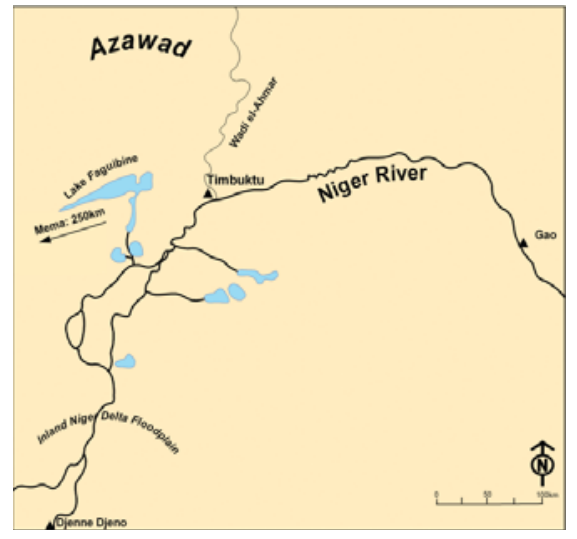

Source: Antiquity Journal 84(2010):1-13, Retrieved on 20/03/2013 from http://antiquity.ac.uk/ant/84/ant840001.htm 
The legendary city of Timbuktu was founded as a commercial centre in West Africa 800 years ago. It is known today for being deserted and ravage by war. However, this was not the case in the past. For more than 600 hundred years ago, Timbuktu was a significant religious, cultural and commercial centre whose resident travelled out to the neighbouring African countries to acquire knowledge and engaged in commercial activities. At that period, Timbuktu was at the height of its commercial and intellectual development. Merchants from Libya, Algeria and numerous other cities of North Africa gathered there to buy gold and slaves in exchange for the Saharan salt of Taghaza and for North African cloth and Horses (Encyclopaedia Britannica, 2013).

The famous contribution of Timbuktu to Islam and world civilization is its scholarship and the books that were written and copied there, began from $14^{\text {th }}$ Century. It was a city famous for the education of important scholars whose reputations were pan-Islamic. The city scholars many of whom studied in Mecca and Egypt numbered some 25,000 (Encyclopaedia Britannica, 2013). The brilliance of the University of Timbuktu was without equal in all of sub-Saharan Africa and was known throughout Islamic world.

The aim of this paper is to review the trend of Timbuktu civilization from prehistoric period up to the current state of its political impact of the region. Emphasis is laid on the role Timbuktu played in African Islamic history serving as academic and commercial centre. The objective of this paper is to reveal the fact that Africa has a long Islamic civilization by providing evidences from reliable sources of the symbolic representation of the influence of the early schools and universities that existed in West Africa. For the purpose of presentation, this paper is divided into 5 sections.

The first section digs out information about civilization in Timbuktu from pre-historic period and the nature of settlement that existed in this historical rich city. Next outline talks about the role of Timbuktu as academic and commercial centre in African history. Subsequent section explains the role early heroes played towards the development and civilization of Timbuktu's Islamic and commercial centre while the fourth section explains chronologically the ruling systems that Timbuktu underwent since its inception up to its current state. Finally, this paper gives the general conclusion about Timbuktu civilization and its significance in Islamic History.

\section{Timbuktu Civilization in Prehistoric Period}

It is widely believe that Timbuktu was founded in the $12^{\text {th }}$ century AD by Nomadic Tuareg. However, the human history in the Timbuktu region is deeper than the historical Tuareg settlement. Based on the archaeological work done by many experts in the region, it was discovered that the massive prehistoric urban society of Timbuktu region persisted for around 1500 years ago (500BC-AD1000) longer than many of the better known older world civilization.

The first archaeological research was conducted by the French colonist in 1950's in Azawad (a territory situated in Northern Mali). The research led to the discovery of Late Stone Age (LSA) sites along the river banks of now desiccated water bodies with finds such as stone tools, human and animal remains, harpoons and ceramics ( Monod T ; Mauny, R 1957). Also, in 1964, Alain Gallay and his team of specialists produced evidences of diverse heterogeneous sites of different types clustered together near ancient water bodies (Gallay 1966). Such research provides information about late Stone Age occupations that have relevance to the greater understanding of the later prehistoric occupations and civilization, both at Timbuktu and within the greater middle Niger.

In 2009, a new research was carried out by Department of Anthropology Yale University which was aimed at developing a ceramic chronology and establishing a context for the prehistoric settlements in Timbuktu region. The result of the research reveals that an organized setting of settlement had existed in Timbuktu. The settlement patterns are believed to represent an expansive urbanism possibly characterised by hierarchical power relationship, that these settlements took the form of tells (ancient mound) each of them surrounded by dozens of smaller satellite sites (McIntosh, R et al 2009). Based on archaeologist findings in Timbuktu, it is clear that highly dense population and an original urban civilization emerged in the first or even second millennium B.C in this $170,000 \mathrm{~km}^{2}$ arid land without the influence or stimulation from the Mediterranean or Egypt. Timbuktu's evolution was one of the most sustainable social epic in the ancient world.

\section{The Role of Timbuktu Accademics and Its Commercial Centers in African Islamic History}

The ancient West African city of Timbuktu was once a vibrant centre of scholarly activities, known throughout the Islamic world. It had played significant role in the wide spread of Islamic knowledge in Africa, specifically in West Africa through well established institutions of learning that existed centuries ago. By the mid of $16^{\text {th }}$ century- the city boosted well over 150 schools (Saad 1986). These schools had well organised curriculum that gave students vast knowledge of different 
fields of study. The Islamic religious courses formed the core of the academic syllabus, including Quran interpretation (Tafsir), the traditions of the prophet (Hadith), Jurisprudence (figh), sources of Law (Usul) and doctrinal theology.

Apart from the religious courses, students were also required to study Grammar (nahwl), lettering style and rhetoric (Balagah) and Logic (Mantiq). Among the schools that were established, Sankore University founded around $14^{\text {th }}$ century, is one the oldest High institution of Islamic learning that survived till today in West African history. It was initially a mosque (Masjid in Arabic) built by the great emperor of that time (Mansa Musa) in the year 1327. By the end of Mansa Musa's reign (early 14th century CE), the Sankore Masjid (a great tawny, pyramid structure laced with protruding wooden support beams) had been converted into a fully staffed Madrassa (Islamic school or in this case university) with the largest collections of books in Africa since the Library of Alexandria. The level of learning at Timbuktu's Sankoré University was superior to that of all other Islamic centres in the world. The Sankoré Masjid was capable of housing 25,000 students and had one of the largest libraries in the world with between 400,000 to 700,000 manuscripts (Said H, Noël. K 1975) Sankore University had successfully produced engineers, architects, astronomers and well renowned Scholars who competed with their contemporaries in other dynasties. Al- Wazan found "a great store of doctors, judges, priests and other learned men" to be graduates of the city's illustrious schools" (Tahir Shah, 1995)

\subsection{Sankore Madrassa}

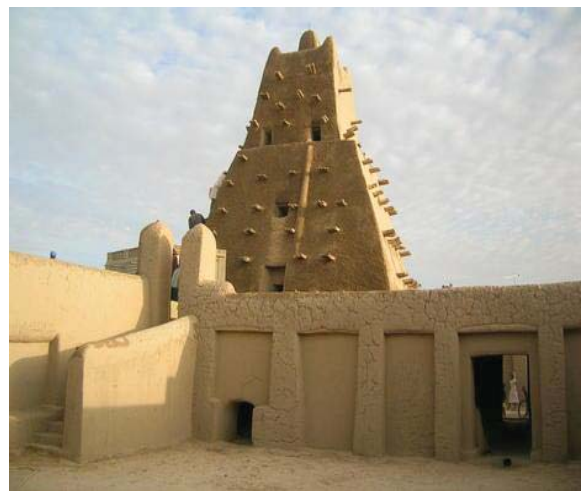

Source: This picture is adopted from UNESCO List of world Heritage in Dangers, Retrieved on 25/05/13 from http://whc.unesco.org/en/danger

Although, this University had undergone series of subjugation by several colonial masters which resulted in the deterioration in quality of education offered there and is currently under threat of desertification, but its contribution in medieval African education can never be under estimated. The kudos made by great Ghana nationalist Kwame Nkruma in his inaugural speech on 25 November 1961 at University of Ghana can serve as a reference of the extent and importance of earlier Academics centres that existed in Africa. Nkruma complimented Timbuktu and Walata for their contribution to African education. He singled out University of Sankore. He says "If the University of Sankore had not been destroyed, if the University of Sankore as it was in 1591 had survived the ravages of foreign invasions, the academic and cultural history of Africa might have been different from what it is today" (Shamil, J Souleymane, B.D 2008)

Other monumental landmarks that revealed the long term existence of Timbuktu as Islamic and Scholarly centre are the three great mosques, namely Djingareyber, Sankore and Sidi Yahia. Built in the early $15^{\text {th }}$ century, these mosques still stand today fortunately as testimony to the grandeur of Timbuktu as result of restoration efforts made by Malian government and non governmental bodies such as United Nations Educational, Scientific and Cultural Organization (UNESCO) to preserve these unique features.

Timbuktu civilization and its influence in shaping West African Islamic history has it stem rooted from the fortuitous placement of Timbuktu at the crossing of the Niger River and major caravan route that continuous to Morocco in the North and swings towards the modern day state of Sudan across the Sahara desert; as well as one of the major routes for pilgrimage to Mecca, these were some of the factors that made it an exceptional location for trading in Tran-Sahara region. This brought with it wealth and culture (Bovill, 1958). Arab Muslims began to patronize this trading centre. Visiting traders and or travellers mostly from Ghana and other parts of West Africa converted to Islam through encounter with Scholars that resided there for Trading. At its height during $16^{\text {th }}$ century, Timbuktu dominated West Africa in trade and 
export. Al - Wazan wrote that "The rich king of Tombouto keeps a magnificent and well furnished court. The coins in Tombouto are Gold. There is a most stately temple to be seen, the walls of which are made of mortared stone; and a princely palace also built by a most excellent work man of Granada. Here are many shops, craftsmen and merchants, and especially of such as weave linen and cotton cloth." (Tahir Shah, 1995)

Many commodities were traded in Timbuktu, ranging from cloth, salt, gold, slaves and scholarly books written and copied there. The most astonishing fact was that, books were the most valuable merchandize traded in Timbuktu. This was noted by the $16^{\text {th }}$ century traveller Leo Africanus who wrote that "Hither are bought divers manuscripts or written books out of Barbary, which are sold for more money than any other merchandise (Saad; 1983). This could be seen as an evidence of the long existence of Islamic civilization and quest for seeking Islamic knowledge in African history. These books popularly known as 'Timbuktu manuscripts' have been for long unique treasures that draws attention of Scholars, researchers, world heritage preservers' and constituted authorities. These scripts cover a wide range of subjects such as medicine, astronomy, mathematics, to mention but few.

Some of these manuscripts were written in local languages including Songhai and Tamasheq (Lydia, P 2007) but most of the scripts were authored in Arabic.

The pattern of Arabic scripts used in Timbuktu were ultimately derived from Kufic and Hijazi forms of Arabic writing developed in Iraqi and Hijaz(a region in the present day Saudi Arabia) during the eighth and ninth centuries (Global gateway, 2007). These forms of writings underwent some modifications due to chain of transmission from Asia to North Africa crossed the Sahara Desert and finally to Timbuktu where scholars and scribes further developed the scripts. However, the manuscripts copied and authored in Timbuktu were basically written in 3 forms of scripts, the 'Saharan' named after the desert that surrounding the city, the 'Sudanic' meaning the belt of open farmlands that extends from East Africa to the Lands just south of Timbuktu in West Africa and the third West African form of Script writing is 'Suqi' literally means the Market scripts. While several Scripts were authored and copied in Timbuktu, its scholars also imported books from other parts of the Islamic world. Scholars returning from pilgrimage further augmented Timbuktu's manuscript collections over the centuries and study in other centres of Islamic learning, often copied by their own hands (Mary, M 2006).

Another amazing fact is that, Islamic written culture particularly during the Middle Ages was brilliant and incomparable than anything known in contemporary Europe, until the invention of printing with movable type in the $15^{\text {th }}$ century. (Bloom, 2001). "Despite the absence of printing press in Islamic lands as of then, the wide spread of written knowledge is considered comparable (if not superior) to the spread of written culture in china following the adoption of large scale printing in the $10^{\text {th }}$ century"

\subsection{Timbuktu Manuscripts}

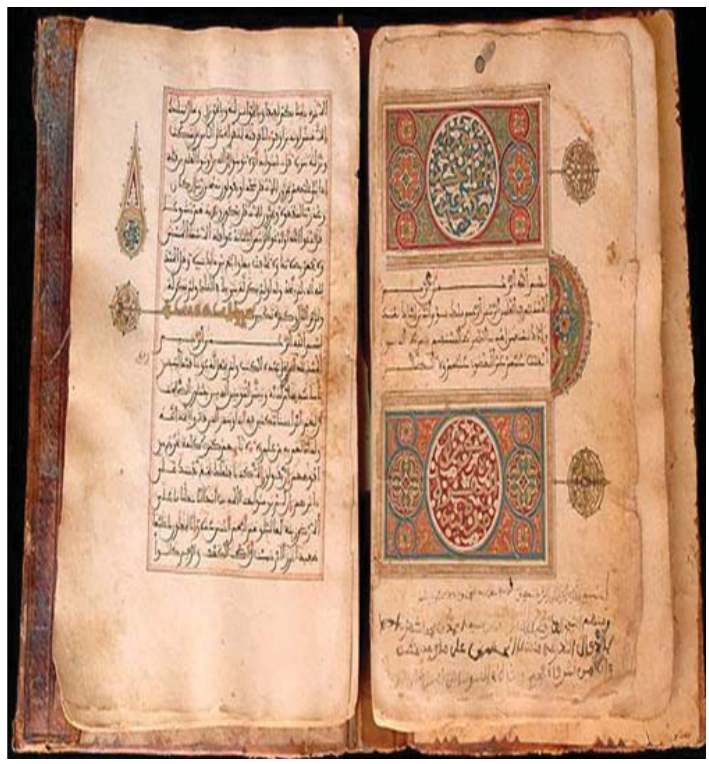


Source: A Copy of the Holy Koran. According to notes in the text, it was bought for a Moroccan king for a sum of gold. This photo is adopted from New York Times Company 2007.Retrived from http://www.nytimes.com/imagepages /2007/08/07/world/07mali.2.ready.html on 26/05/2013.

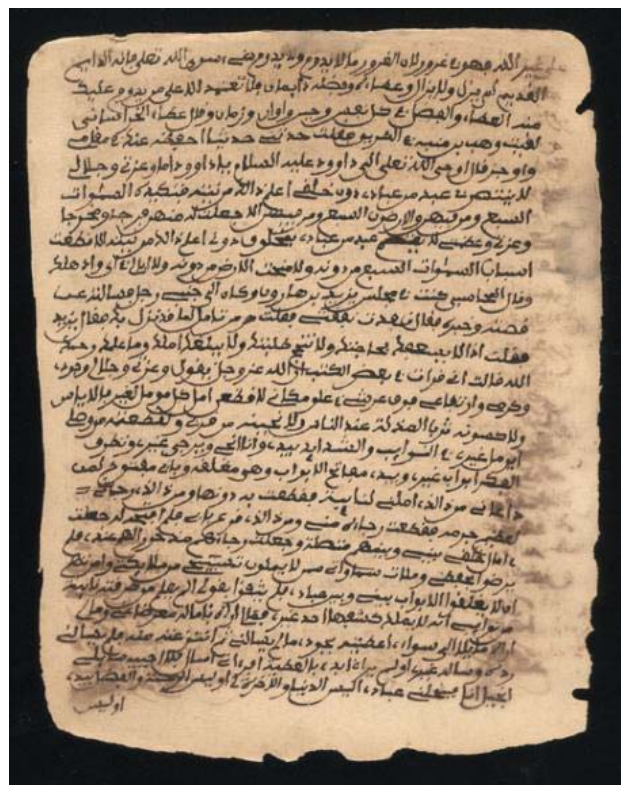

Source: This copy is adopted from Library of congress global gateway retrieved from http://international.loc.gov. 26/05/2013

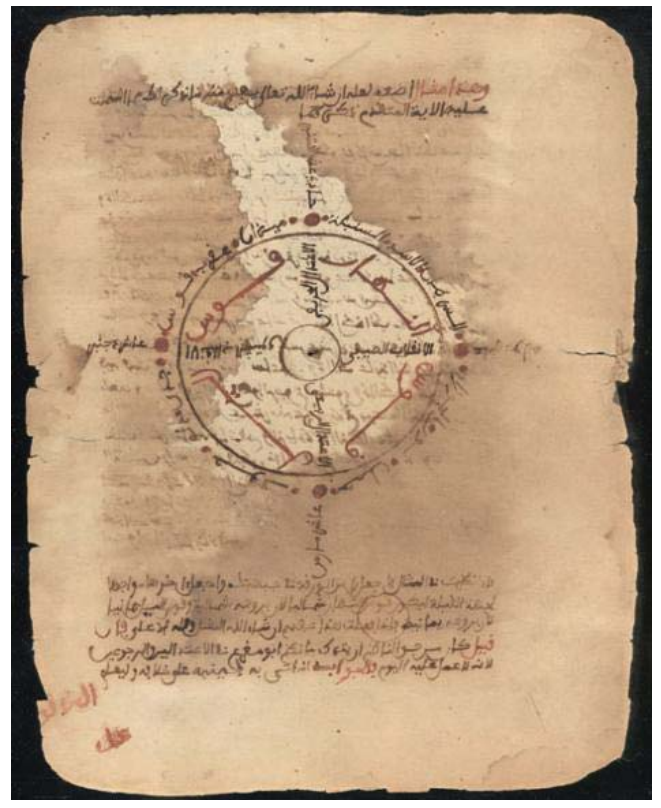

Source: This copy is adopted from Library of congress global gateway retrieved from http://international.loc.gov. 26/05/2013 
Within Timbuktu, there existed an active copying and Scribal industry (Hunwick, 2003) that ensured a continual production of manuscript for the consumption of scholars, student and literate citizens. Thousands of books authored and copied in Timbuktu were kept and preserved by households. The number of manuscripts owned by a family was an indication of scholarly status of that family. Currently, many libraries are established in Timbuktu where several information on various field of knowledge can be harnessed. These libraries such as Mamma Haidara commemorative Library, the Library of Sheikh Zayni Baye of Boujbeha and Ahmed Baba centre and its private libraries continue the tradition of the families who established them by preserving and making available these valuable works, which until recently were unknown outside Mali. Scholars in the fields of Islamic studies and African studies are awed by the wealth of information that these manuscripts provide. Indeed, the use of these works by scholars will likely result in rewriting Islamic, West African, and world history.

In a nut shell, the manuscripts in Timbuktu whose subjects cover every topic of Human endeavours are indicative of the high level of civilization attained by West Africans during the middle ages and early modern period. The ancient manuscripts preserved at private homes and libraries in Timbuktu serve as eloquent witnesses to the influence of Timbuktu beginning in the 15th and 16th centuries.

\section{The Role of Notables and Scholars in Timbuktu Development}

Every nation underwent significant landmarks in their history highlighted great and talented men, women and leaders who sacrificed their time, energy and resources towards lifting their empire to a greater height. Timbuktu had once had such great people who exerted continues influence upon the organization of this great city throughout its history. These people constituted of early rulers and scholars. Many of whom contributed immensely in developing the Islamic academic centres as well as commercial centre in Timbuktu.

Timbuktu had experience the rule of different tsars under different empires, starting under Ghana Empire and later ruled under Mali Empire in the early 14 ${ }^{\text {th }}$ century, to Songhai Empire who absorbed the city in 1468 and finally to ill fated Moroccan conquer in 1591. Among the Emperors that ruled this great city, Mansa Musa (also known as Kankan Musa) goes with the credit of developing the city of Timbuktu, making it a renowned Scholarly and commercial centre in the world history. Mansa Musa was the tenth Mansa (meaning king of Kings) of the great Malian Empire. Born in $1280 \mathrm{ca}$ (Joe, P. 1991), he was one of the wealthiest, strongest and influential emperors of his time. The North African Scholar AlUmari who lived in Cairo declared Mansa Musa "the most powerful, the richest, the most fortunate, the feared by his enemies and the most able to do well to those around him" (Joe palumbo, 1991). Mansa Musa was a devoted Muslim, committed to the propagation of Islam. His philosophy about Islam was that "Islam was the foundation of the cultural world of the Eastern Mediterranean; therefore, he would spend much time fostering the growth of Islam in his empire" (Goodwin, A.J.H 1957). This was his rationale behind making Timbuktu a scholarly centre. Also, His pilgrimage to the Holy land of Mecca in 1324 was associated with amazing adventures which made him famous in North Africa and Middle East.

The astonishing riches displayed and large entourage accompanying this great King was a topic of discussion up to the current days of modern civilization. His journey through Egypt was long remembered because Musa took with him about eight thousand $(8,000)$ soldiers, courtiers and servant. 60,000 among his followers drove 15,000 camel laden with gold, perfume, salt and stores of food in a procession of unrivalled size. (Tahir, S. 1995). This astonishing wealth demonstrated captured the imagination of both East and West, albeit for very different reasons. In 1620, the English explorer Richard Johnson wrote hyperbolizing the riches in Timbuktu. "The most flattering reports had reached Europe of the Gold trade carried on at Timbuktu. The roofs of its houses were presented to be covered with plates of gold, the bottom of the rivers to glistering wit precious metal and mountains had to be excavated to yield a profusion of the Metallic treasures" (Tahir, S 1995). The people of Cairo earned a multitudinous sum of his wealth that he upset the value of goods on the Cairo market. His lavish wealth influence scholars and intelligent men from Egypt and other part of the world to accept his request to follow his entourage back to his empire making his empire scholarly richer. Also traders, merchants and business tycoon's forecasted the economic factors of this great empire and venture into trading with it.

The role Mansa Musa played in developing the Scholarly activities in Timbuktu was seen in his great effort in building infrastructures in the city of Timbuktu. It was marked when the caravan of emperor Musa arrived on the scorching day in 1325 from Mecca, he commanded the Group of architects he came along with from Andalusia and Cairo to build a magnificent Mosque in Timbuktu and built a new palace for him making Timbuktu the capital of his territory. The work was led by Granada architect and poet Abu Ishaq Al- Sahili who travelled with him from Mecca. The mosque was built in the western corner of the city. It was named "Djinguereber" derived from the Arabic word "jami'al Al-kabir". 
The mosque was so perfect that British traveller Henry Bath wrote that "The mosque by its stately appearance made a deep impression on mind includes nine naves of different dimensions and structures (Tahir, S 1995)

Sankore University was re-staffed during the Era of sultan Musa with jurist, mathematicians, and astronomers and high learn people having expertise in different fields of study. As a result of sultan Musa's influence, Timbuktu became an Islam centre. The city's markets brought in merchants from different parts of African kingdoms, and Islam was spread through the markets, making Timbuktu a new area for Islamic scholarship. News of the Malian empire's city of wealth even travelled across the Mediterranean to southern Europe, where traders from Venice, Granada, and Genoa soon added Timbuktu to their maps to trade manufactured goods for gold.( Marq De Villiers, et al 2007).

Moreover, Mansa Musa's significant role was not limited to the development of Timbuktu; rather his influence covers the then Saharan region. During the great political turmoil in Western region of Western Sudan, that followed the collapse of Ghana Empire, the main challenge was how to restore peace and harmony in the region. Mansa Musa single handily solve the chaos.

Mansa Musa reigned in 1312-1325. By the time of his death, Mali has grown into one of the largest empires of the world. (Joe. P, 1991). Through his successful 25 years on throne, Mansa ruled large part of central and western regions of western Sudan. He did that meticulously displaying high level of justice, that Ibn Battuta travelling 12 years after the demise of sultan could found "complete and general safety in the land"

Looking at the contribution made by scholars in developing Timbuktu, it could be seen as human development, that is to say, their influence was not materialistic or physical, but rather intellectual. They impacted knowledge in people, leading to a refine spiritual development. Scholars in this traditional reach city were the leaders of the urban community, its spokesmen, the rulers and the regulators of its public affairs. In their multiple position as elite and significant in the society, they could mobilized wide population of the community given them a considerable stand in the internal affairs of their municipals. Considering the religious-cum-political organization of Islam in the city, their influence was strongly felt at the administrative level as well.

Some of the contributions attributed to scholars in developing Timbuktu have been observed by prominent writers in their contribution on the medieval History of Timbuktu. Sekene Modi Cissoko have affirmed that "The high level of recognition enjoyed by the city was as a result of institutions of knowledge established by hundreds of scholars in the city leading to the formation of vibrant centres of learning in Songhai Empire" (Cissoko, S, M. 1969). Hunwick, on the order hand ascribed the phenomena of autonomy earned by Timbuktu to "The unusual dynamism exhibited by the scholars, and especially by Aqit family among them during that period" (Hunwick,, J.O 1962) Thousands of Scholars have existed in Timbuktu in the middle ages. Many of whom contribution to Timbuktu and Islamic community at large is worth commendation. In quest of the influence of these scholars to humanity, there is need to revisit the past.

Among the Scholars that existed in Timbuktu, history will never forget the positive impact made by a rear gem, a philosopher, a martyr, a jurist, an intellectual and distinguished scholar in person of Abu al-Abbas Ahmad ibn Ahmad alTakruri Al-Massufi al-Timbukti popularly known as Ahmad Baba (reign 1556-1627). He was the most prominent scholar during his time and often noted as Timbuktu greatest scholar (New York Times, 2007). he was born in the middle ages of $16^{\text {th }}$ century, the period when Timbuktu was at apex of its cultural and intellectual deliverance, meaning that, he acquired most of his Islamic knowledge in Timbuktu, A descendant of Qadis (meaning Judges) and Scholars, whose influence gave him an upper hand to acquire high education in Islamic disciplines. He started his early education under the mentorship of Muhammad Baghayogo Al-Wangar, with whom he read the classical texts of Hadith (traditions of the prophet), Nahw (Arabic Grammar), Tafseer (exegesis), figh (jurisprudence) Tawhid (theology) and tasawwuf (mystism).

The contribution of Ahmad Baba to the development of Timbuktu was first noticed during the time of Moroccan conquest in 1591 where he openly opposed the Moroccan occupation and became the leader of the intellectual opposition to the invaders (Encyclopaedia Britannica, 2013). Beign respected for his character and teaching, he succeeded in mobilizing the wider sector of the city's population to revolt against the Moroccans. In 1593, two years after the invasion of Moroccans, the Sultan of Morocco Mulay Ahmad Al-Mansur ordered the arrest of the prominent scholar where he was accused of sedition. He was deported to Morocco and kept under house arrest in Marrakech for two years and later released with the condition of not living the city. During his stay in Marrakech, he taught different subjects, covering theology, grammar, rhetoric and Maliki law at jami'al Shurafa, the main Mosque University of Marrakech. His Majlis attracted distinguished scholars, students and dignitaries. He wrote 29 books while teaching in Morocco. "The Moroccan period was in fact the most prolific of his literary career; he wrote more than half of his works during this time about 29 out of 56 recorded" Lalou. M et al. (2008).

Ahmad Baba was a prolific writer that authored several books covering wide range of areas. A brief introduction that underlines central themes of some of Ahmad Baba writings are (Mi'raj al-su'ud ila nayl hukm majlab al-sud) or (al- 
Kashf wa al-bayan li-asnaf majlub al-Sudan) One of his fair works also noted was the biography of Muhammad Abd alKarim al-Maghili, a scholar and jurist responsible for much of the traditional religious law of the area. This became one of the principal texts for study of the legal history of the Western Sudan (Batrān, 'Abd-Al-'Aziz 'Abd-Allah, 1973). Another important role Ahmad Baba played in the history of African Islam was his work (Muqaddima) on the legend or misconception on origin of Black people. In the ancient times, it was widely believed that black people belonged to a cursed race; destined to servitude in the expiration of 'original sin' that conversion to Islam was barely able to erase.

This myth which was originated from the Bible based on the story of Prophet Nuh (A.S) that cursed his son Ham and that the descendant of this disgraceful son were destined to be slaves of the descendant of Sam and yafith until the end of time. The legend (which the Qur'an does not mention) had a curious interpretation by Arab Authors. The author of the famous Sira (historian), Ibn Ishq believed to have been the first writer on this subject. Ahmad Baba tried to prove the mythical character of this tradition in his Muqaddimma that this is not related to the darkness of the skin of his descendants. "There is absolutely no difference between the different human races, whether they come from Ham or another. It is possible that Noah's curse if it has fallen upon a certain number of Ham's descendants has not fallen upon all. He adds, supposing the latter is the father of the people of the Bilad al- Sudan, God is too merciful to make millions atoned for the fault of one man" (Lalou. M 2008).

This soft tuned approached by this rear gem, changed the wrong perception of so many misled people about the origin of blacks. After the Moroccan sultan has passed away in 1603, the heir to the throne, the son of Al-Mansur gave Ahmad Baba the permission to return to his country. He arrived at Timbuktu on 27 March 1607 after 14 years on exile. He spent the rest of his life in his home town of Timbuktu, devoting his time in writing and teaching scholars and students who came from far and near. Ahmad Baba died on 22/05/1627 in Timbuktu where he was buried according to Islamic rites. He succeeded in graduating distinguish Scholars among his students, within Timbuktu province and international. Some of his eminent disciples were Abu al-Abbas Al-Maqqari, the imam and Mufti of Qarawiyyin Mosque in Fez, Abd AlRahman al- Sadi the author of famous book "Tarikh Al-Sudan" meaning the history of Sudan. The Tarikh traces the history of Timbuktu from its founding until the time of its writing. The description made by this distinguished scholar is so reliable and accurate that, 250 years after it was written, A French journalist Felix Dubois used it as his guide book (Tahir, S 1995). "The author displays an unusual conscientiousness, never hesitating to give both versions of doubtful events" (Dubois, 1897). In Timbuktu and its neighbourhood, Ahmad Baba is considered the Muja hid of the century. The central library in Timbuktu, the Ahmed Baba Institute (which stores over 18,000 manuscripts) is named in his honour. (Curtis Abraham, 2007)

\section{Ruling System in Timbuktu}

Timbuktu had undergone the rule of various dynasties and Europeans colonization. In 1468, the city was conquered by the Songhai ruler Sonni Ali whose regime lasted for about 30 years. He was described as a tyrant who was generally ill disposed towards the city's Muslims scholars. However, his successor Muhammad I. Askiya reigned (1493-1528) happened to be the first ruler of the New Songhai used the scholarly elite as legal and moral counsellors. In 1591, the city was conquered by Morocco which resulted in Timbuktu declination. Its scholars were apprehended in 1593 on suspicious of mobilizing people to revolt against Moroccans; some were killed during the struggle, while others exiled to neighbouring countries. European explorers reached Timbuktu in the early 19th century. The first European explorer to reached the soil of Timbuktu was the Scottish explorer Gordon Laing in (1826), followed by the French explorer RenéAuguste Caillié in 1828. Caillie, who had knowledge of Islam and could communicate in Arabic language, became the first explorer to return to Europe with vast knowledge of the city and its potentials. In 1853 the German geographer Heinrich Barth reached the city during a five-year trek across Africa. He, too, survived the journey, later publishing a chronicle of his travels.

Based on the information given by Caillie about the wealth and riches in Timbuktu, the city was captured by the French in 1894. They partly restored the city from the desolate condition in which they found it by providing basic amenities, but no any infrastructure was put in place. In 1960 it became part of the newly independent Republic of Mali. Timbuktu is now an administrative centre of Mali. In the late 1990s, restoration efforts were undertaken to preserve the city's three great mosques, which were threatened by sand encroachment and by general decay. An even greater threat came in 2012 when Tuareg rebels, backed by Islamic militants, took control of the northern part of the country. The Tuaregs claimed the territory, which included Timbuktu, as the independent state of Azawad. However, the Tuareg rebels were soon supplanted by the Islamic militants, who then imposed their strict version of Sharî'ah (Islamic law) on the inhabitants. The Islamic militants-in particular, one group known as Ansar Dine-deemed many of Timbuktu's historic 
religious monuments and artefacts to be idolatrous; to that end; they damaged or destroyed many of them, including tombs of Islamic saints housed at the Djinguereber and Sidi Yahia mosques.

\section{Conclusion}

The manuscripts in Timbuktu add great depth to our understanding of Africa's diverse Islamic history and civilizations. By harnessing these scripts through intense research, academics and students of Islamic studies, African history, typography and African literature would have an opportunity to play a unique role discovering Timbuktu's contribution to history of ideas. Despite the dunes surrounding this great city in all directions, and trapped in a severe and perfidious climate, the fact that this fable city rose and prospered for about 800 hundred years is remarkable. That it also became a centre of scholarship so fertile that it advanced the world wide community of Islam learning is astonishing. But more surprising, still is that Timbuktu intellectual tradition remained largely intact generation after generation.

\section{References}

"Timbuktu" Encyclopaedia Britannica Online Academic Edition. Encyclopaedia Britannica Inc. 2013. Retrieved frohttp://www.britannica.com/Ebchecked/topic/596022/ Timbuktu.

Batrān, 'Abd-Al-'Azīz 'Abd-Allah (1973). "A contribution to the biography of Shaikh Muḥammad Ibn 'Abd-Al-Karīm Ibn Muḥammad ('Umar-A 'Mar) Al-Maghïlī, Al-Tilimsānī", Journal of African History 14 (3): 381-394

BLOOM, JM. (2001). Paper before print: the history and impact of paper in the Islamic world. New Haven; London: Yale University. Journal of the American Institute for Conservation Vol.42, No.1 Architecture Issue (spring, 2003). 121-134

Bovill, EW. (1999). The golden trade of the Moors. Princeton, Nj: Markus Wiener Publishers.

Cameron Village Regional Library (2010). Teaching Timbuktu: Training and resources for the legacy of Timbuktu Exhibit.

Cissoko, Sekene Modi, "L" Intelligentisia de Tombouctou aux XVe et XVle Siecles" Bulletin de I ' Institut foundamental D ' Afrique Noire, Tome XXXI, 1969 pp 927-952

Curtis Abraham, (2007)"Stars of the Sahara," New Scientist,: 38

Gally, A (1966). Quelques gisement neolothiques de Sahara Malien. Bulletin of African societies 36(2): 167-208

Goodwin, A.J.H. (1957). "The Medieval Empire of Ghana", South African Archaeological Bulletin 12: 108-112

Hunwick, J. (2003). the Timbuktu Manuscript Tradition. IN. Tinabintu, Journal of African natural affairs. V1.N2 pp 1-pp2

Hunwick, J.O "Ahmad Baba and the Moroccan Invasion of the Sudan (1591)" Journal of the historical society of Nigeria, pp311-328

Joe, P. (1991). Mansa Musa: African King of Gold. National Centre for History in the schools, University of California, Los Angel.

Lalou. M, Lindsay. H, Gerald. K ( ed ) (2008) Timbouctou Manuscript project retrieved from http://www.tombouctoumanuscripts.org limages/uploads/ScriptandScholarshipCatalogue.pdf./ on 25/03/2013

Marq De Villiers, Sheila Hirtle (2007) Timbuktu: Sahara's Fabled City of Gold. Walker and Company: New York ;McClelland \& Stewart,

Mary M, (2006). safeguarding Africa's literary heritage: Timbuktu rare manuscripts project. Retrieved from http://eprints.rclis.org/7831/1 /liasa_wchelig_colloq.06.pdf on 05/06/13.

McIntosh, R (2009). Late halocene Paleoclimate Reconstruction and long-term Human Response in the Region of Timbuktu, Mali (West Africa). Department of Anthropology Yale University, ANTIQUITY 84(2010); 1-3

Monod, T. Mauny, R (1957). Decouverte de nouveaux instruments en os dan l' oust africain, in Clark, J.D (e.d) Proceedings of the third Pan-African congress on prehistory, Livingstone: 242-7. LONDON: Chatto \& Windus.

Resultants Provisoires RGPH 2009 (Region de Tombouctou), Republique de Mali: Institut National de la statistique.

Saad, EN (1983). Social History of Timbuktu: the role of Muslim Scholars and Notables; 1400-1900 Cambridge; Cambridge University

Tahir S, (2009) The Islamic legacy of Timbuktu. Timbuktu Educational Foundation. Retrieved from http://timbuktufoundation.org/?nr=0 25/05/2013

Timbuktu Hopes Ancient Texts Spark a Revival". New York Times. August 7, 2007. Retrieved on 06/06/2013. From http://www.nytimes.com/2007/08/07/world/africa/07mali.html?pagewanted=all\&_r=0

Shamil, J, Souleymane, B.D (ed) (2008) the meanings of Timbuktu. South Africa; HSRC Press. 